\title{
Predictive ecosystem research in the Wadden Sea
}

\author{
K. Reise \\ Biologische Anstalt Helgoland, Wattenmeerstation Sylt; D-25989 List, Germany
}

\begin{abstract}
Predictive ecosystem research needs a pluralistic approach. Retrospective studies reveal the initial causes of ongoing ecological change. In the Wadden Sea, inherent ecosystem stability may be falsely assumed, because the effects of modern coastal architecture and of anthropogenic eutrophication to some extent complement each other. Expected environmental changes often have corresponding phases in the past which may serve as a model to predict ecological implications. Historically, quantitative ecology entered the Wadden Sea, via fisheries research, from the oceanic side. Quantified material fluxes may reveal imbalances which are indicative of the rough direction of ecosystem change. For ecosystem research to contribute to the maintenance of the Wadden Sea as a centre of coastal organisms, quantitative knowledge of resources and ecosystem metabolism must be supplemented by qualitative knowledge of habitat requirements and species interdependences. Qualitative ecology entered the Wadden Sea from the landward side. Extending this approach to anticipatory field experiments may help to predict ecological changes at the species level.
\end{abstract}

\section{INTRODUCTION}

Physically the Wadden Sea is an edge; a gigantic body of water passing to and fro with the tides. With its $8000 \mathrm{~km}^{2}$, the Wadden Sea comprises merely $1.4 \%$ of the size of the North Sea, and about $1.6 \%$ of its riverine watershed (including the river Rhine with its tributaries). Accordingly, the physical properties of the Wadden Sea waters are set by processes and events in these adjoining ecosystems.

Biologically, however, the Wadden Sea is a centre. Organisms tend to aggregate at habitat edges. Seals choose sand banks at tidal inlets as peak haulouts, and forage in the channels. For East Atlantic wading birds, breeding in the north and wintering in the south, the Wadden Sea is an essential staging area to replenish their fat reserves. Fish, shrimp and crabs use the tidal flats as nurseries. The populations of lugworms ( Arenicola marina L.) and tellinid clams (Macoma balthica [L.]) concentrate at the landward edges of the tidal flats, using these as nurseries. Benthic diatoms are most apparent on intertidal mud in sheltered bays. There are many groups of organisms which attain their peak densities in the Wadden Sea; thus, the ecological importance of this coastal area resides in its biological components rather than its physical attributes. Any ecosystem research in the Wadden Sea has to be aware of the ecotone properties of this transition zone between the sea and the land, with its physical transportation of water masses, and organisms migrating, or drifting in and out. Ecosystem research cannot stop at the geographical confines of the Wadden Sea.

With regard to ecosystem processes, the Wadden Sea is not uniform. A first order 


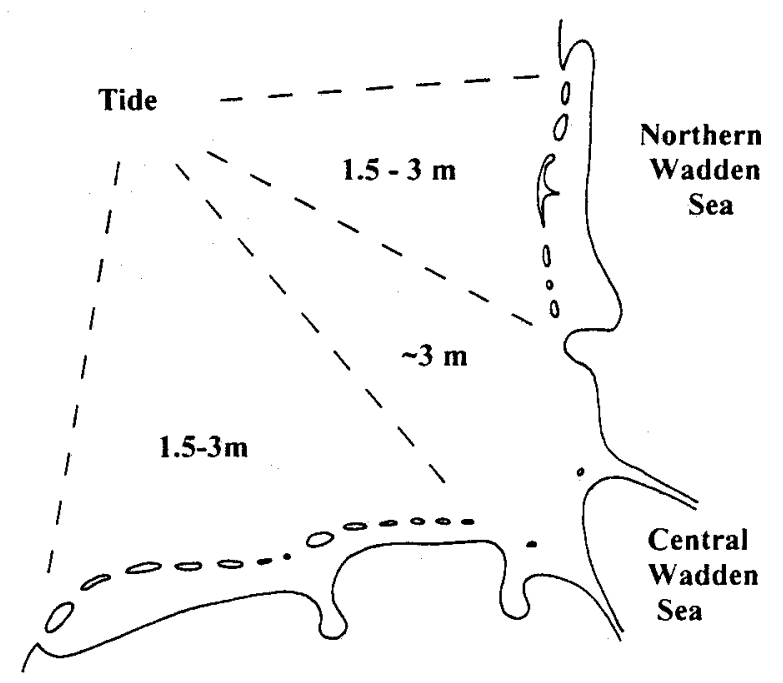

Southern Wadden Sea

Fig. 1. The Wadden Sea consists of three major regions. Approximate tidal ranges are indicated (see text)

distinction leads to three major regions (Fig. 1). The northern and southern regions have tidal ranges between 1.5 and $3 \mathrm{~m}$. A corollary of this range is a chain of barrier islands and sand ridges parallel to the coast (Hayes, 1975). The Central Wadden Sea has tidal ranges close to $3 \mathrm{~m}$. The resulting strong on- and offshore currents prevent barrier island development. The northern region faces the prevailing westerly winds, while the southern region faces northward. In the north, river entries are small, and variation in salinity is low. In the Central Wadden Sea, river entries are large, and variation in salinity is high. In the south, salinity variations are intermediate. For further regional subdivisions, see Dijkema et al. (1989). Material fluxes and abundances of organisms are expected to differ between these regions. No subregion within the Wadden Sea is representative of the whole.

In this article, the ecological history of the Wadden Sea as well as the history of ecological research in this area is screened for implications relevant to predictive ecosystem research. Predictions should rest on experience of past processes and events. Extrapolations from import-export quantities and turnover rates describe what may be possible. What is likely to be realized should be explored experimentally.

\section{ECOLOGICAL HISTORY}

The ongoing postglacial sea-level rise on the Wadden Sea coast did not monotonously increase during the last 6000 years, which is the approximate age of the Wadden Sea with its present position, size and shape. Phases of retardation in sea-level rise alternated with phases of acceleration. This is documented in vertical sequences of marine-brackish sediments intercalated by layers of limnic-terrestrial peat (Streif, 1989). 
Apparently, there were several reversals between phases of inundation and erosion, and phases of marsh accretion and sedimentation, and these did not occur in concert throughout the Wadden Sea. The local responses to supraregional trends in sea-level rise differed according to specific hydrological and sedimentological conditions. This phenomenon of inherent, ongoing and asynchronous change in geomorphology and hydrodynamics is of importance, when ecological measurements taken at a particular site and time are to be extrapolated.

For 1000 years people progressively interfered with these natural dynamics, first in the south and then in the north of the Wadden Sea (Bantelmann, 1966; Wolff, 1992a). Marshlands were diked and drained. Tidal flats were also diked to create freshwater storage basins, or simply to straighten out the coastline. Natural mud accretion was promoted. Dams were built across tidal flats and channels. The building material for dikes and dams was often extracted from the seaward flats. Erosional shores have been fixed by stone walls. Sluices and storm-surge barriers control the water flow between the sea, land and estuaries. Deep harbours with strong jetties were built, and some channels are permanently deepened by dredging, to let bigger ships travel further inland.

Together these activities resulted in a modern coastal architecture, where the smooth, irregular and dynamic transition of the land blending into the sea is displaced by a seaward, abrupt and straight dikeline (Fig. 2). The relative proportions of habitat sizes have changed. The slope from high tide line towards the subtidal gullies steepened, because the dikeline moved seaward and the gullies became wider (Misdorp et al., 1989).
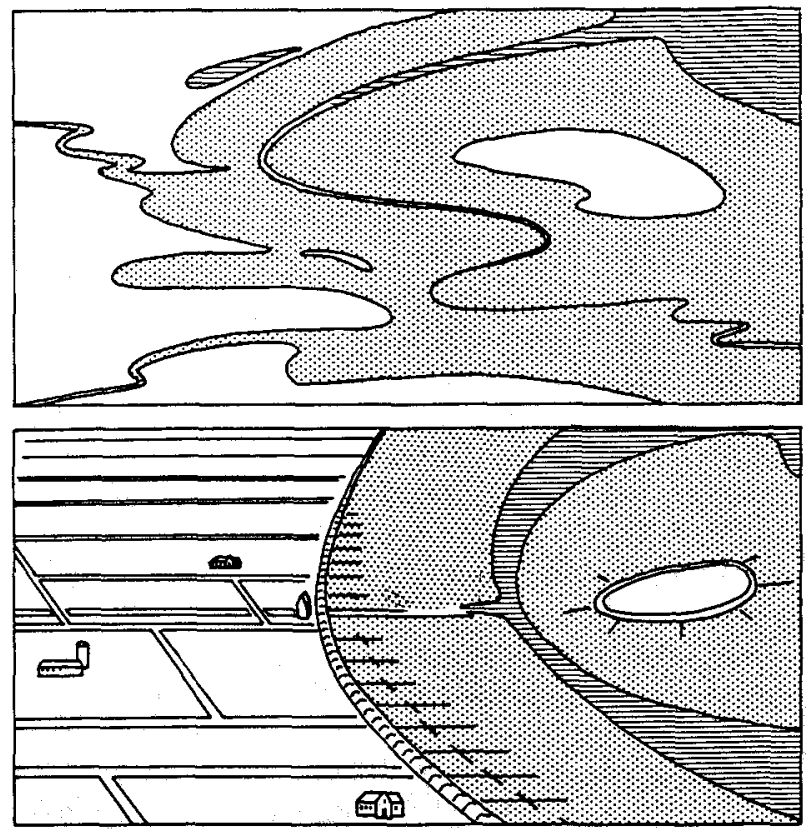

Fig. 2. Pristine (above) and modern Wadden Sea. Tidal flats are dotted, permanently submerged areas are striated 
Table 1. Ecological implications of modern coastal architecture and anthropogenic eutrophication in the Wadden Sea, increase $(+)$ and decrease $(-)$

\begin{tabular}{|lcc|}
\hline Implication & Coastal architecture & Eutrophication \\
\hline Turbulence & + & \\
Salt marshes & - & \\
Sheltered bays & - & \\
Sedimentation & - & \\
Turbidity & + & + \\
Primary production & - & + \\
Deposit feeders & - & + \\
Suspension feeders & - & + \\
Birds and fish & - & \\
\hline
\end{tabular}

These fundamental changes in size and shape of the Wadden Sea ecotone have several ecological implications (Table 1):

(1) In spite of sea-level rise, there are no more landward extensions of the Wadden Sea. Dikes or stone walls prevent the sea gradually dying out and dissipating its energy while flooding the land. Consequently, turbulence has increased.

(2) Embankments and reclamations of the wetlands eliminated salt and brackish reed marshes, thereby decreasing the detrital inputs into the remainder of the Wadden Sea. According to Dijkema (1987), the rate of embankment was faster than the accretion of new marshes. In 1600 , about $15 \%$ of the intertidal zone was covered by salt marshes. Today this is $3 \%$.

(3) Almost all sheltered bays vanished, because at these sites embankments were technically most feasible and cost effective. Such bays were the natural sites of sedimentation and mud accretion. Where bays still exist, sedimentation seems to keep pace with sea-level rise (Frels \& Demuth, 1987). However, the overall amount of sedimentation and mud accretion declined because the sheltered areas most suitable for these processes became scarce.

(4) As a consequence of higher turbulence, and diminished mud accretion in salt marshes and sheltered bays, turbidity in the tidal waters increased. In the Southern Wadden Sea, secchi disc visibility has decreased by $1.4 \mathrm{~m}$ since the 1930 s (Jonge et al., 1993). Dredging of harbours and navigation channels, and the extraction of sand and shell gravel, also contribute to higher turbidity.

(5) Increased turbidity limits light penetration, and hampers photosynthesis in the tidal waters. Together with the loss of salt and reed marshes and the loss of sheltered bays where epipelic diatoms abound, the overall effect is a decrease in primary production within the Wadden Sea.

(6) Deposit-feeders of the benthic fauna presumably had more food when extensive salt marshes still exported detritus seaward, and sizable shallow bays with natural mud accretion and high benthic diatom production were still in existence. Mussels benefit from a moderate increase in resuspended bottom materials, but when turbulence causes high suspended matter concentrations, the clearance rate of filter feeding decreases again (Kiorbøe et al., 1981). Another disadvantage of increased turbidity to suspensionfeeders is the concomitant light limitation of their planktonic food in the gullies. 
(7) It is expected that birds and fish find less food when the benthic fauna is affected. The lost shallow bays were preferred feeding grounds for waders and fish nurseries. In the case of the embanked Zuiderzee, a race of herring lost its spawning grounds and disappeared completely (Wolff, 1992a).

Technogenic substances, fishing, hunting, and tourism aggravated some of these ecological implications of the modern coastal architecture (Wolff \& Zijlstra, 1980; Wolff, 1992b). On the other hand, anthropogenic eutrophication caused a partial reversal. In recent decades, non-diatom plankton increased (Cadée, 1992), green algal mats spread on tidal flats (Reise et al., 1989), and the bottom fauna increased in abundance and biomass (Beukema, 1992). Presumably, these eutrophication effects also increased bird numbers, but this cannot, with certainty, be differentiated from bird protection measures (Vauk et al., 1989; Wolff, 1992a). This enrichment phase of eutrophication eventually proceeds towards depauperated biota when oxygen conditions become deficient (Rosenberg, 1985). At the time, however, eutrophication effects on the ecosystem are opposite to those of the new coastal architecture. The results of such antagonistic changes should not be confused with inherent ecosystem stability, which requires negative feedbacks between processes.

This may exemplify the importance of reconstructing past developments to understand the present state. A retrospective approach is also likely to improve our ability to predict future directions of ecological development. Most of the past processes will also play key roles in the future. Of particular relevance is a combination of ongoing eutrophication with climatic change, and the concomitant acceleration in sea-level rise. The latter will provoke new, ambitious plans by coastal engineers to keep the sea away from the land. Ecologists will be asked to estimate the ecological implications of alternate options. A thorough evaluation is needed of the ecological effects of the seaward progression of the dikeline during the last centuries, particularly in this case. This requires the joint efforts of paleoecological research, historical inquiries, retrospective modelling and field experiments simulating past events. In many respects, the future is merely an extension of the past. Therefore, a sound understanding of the past may be the best precaution to give ecological advice in a changing Wadden Sea.

\section{HISTORY OF ECOLOGICAL RESEARCH}

Two tribes of ecologists invaded the Wadden Sea. One entered the tidal zone from the terrestrial side, and analysed the ecological web primarily with a qualitative approach. The other tribe is of oceanic origin, was nursed by fishery research, and followed primarily a quantitative approach (Fig. 3).

The terrestrial tribe started with Karl Möbius $(1877,1893)$. The natural oyster beds in the Northern Wadden sea suffered from over-exploitation. Möbius was called for, came, and dredged the first ecological community concept from the bottom of the Wadden Sea (Reise, 1980, 1990). His concept is still alive, while the oyster beds are long gone. Möbius viewed an oyster bed as an interacting assemblage of populations. Under the local physical conditions, planktivors, predators and pathogens maintain a community in a state of equilibrium, unless over-exploitation causes a complete reorganization.

Detailed knowledge on interactions among species and with the environment seemed necessary to understand the ecological web. With this attitude, Warming (1904), 


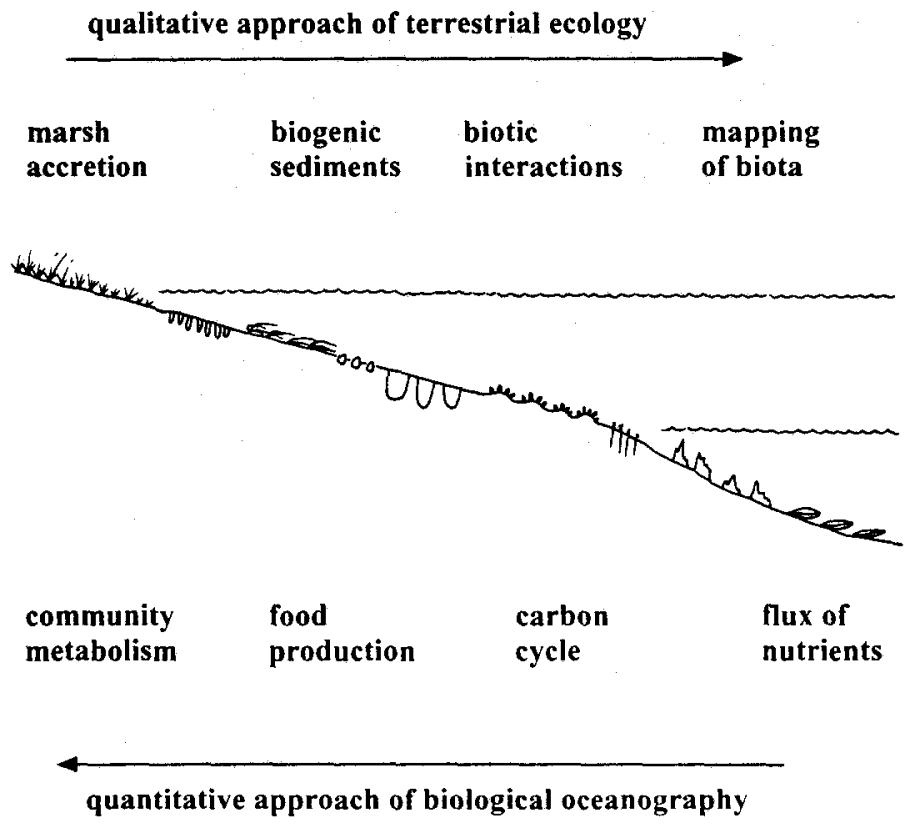

Fig. 3. Topics of ecological research chosen by scientists entering the Wadden Sea from the landward side (above) and from the oceanic side

Wohlenberg $(1931,1937,1953)$ and Linke (1939) analysed salt marsh accretion, biogenic mud formation and other organism-sediment interactions. They also mapped and described the pattern of habitats and species associations, as it was practised in terrestrial plant sociology.

Later cascades along this stream of research included, among others, zonation of arthropod niches in salt marshes (Heydemann, 1967, 1979), field experiment on biotic interactions and organism-environment interdependence on tidal flats (Reise, 1985), and repeated mapping of habitats and organisms in the intertidal zone to trace ecological history (cf. Michaelis, 1987).

This qualitative research on ecological interactions remained separated from quantitative research on the metabolism of the Wadden Sea ecosystem. Inspired by the planktologist Victor Hensen, Dahl (1893) was the first to count the tidal flat fauna per square metre. He found few species, but many individuals, and attributed this to physical harshness and resource richness, respectively. The latter implied that there was plenty to feed upon in the Wadden Sea.

Fishery biologists identified the Wadden Sea as a major nursery area for plaice and herring (Garstang, 1909; Bückmann, 1934). Thamdrup (1935) quantified community metabolism on tidal flats. He found oxygen consumption to be high on tidal flats, compared to that of a deciduous forest floor. In the same region of the Northern Wadden Sea, Smidt (1951) estimated food production in the plaice nurseries, and Grøntved (1962) measured primary production.

Until the 1970 s, ecosystem research in the Wadden Sea was carried out by interdicri- 
plinary individuals. Only then did Dutch projects, in the Ems-Dollard estuary and in the western Wadden Sea (with their joint efforts) start to quantify the carbon cycle and nutrient fluxes. This research was no longer an outgrowth of fishery science. It was stimulated by a concern about the Wadden Sea as a nature area, threatened by embankment, waste discharge and other human impacts (Wolff \& Zijlstra, 1980).

From the quantitative perspective, the Wadden Sea is regarded as an importer of organic particles and an exporter of dissolved metabolic endproducts (Fig. 4), among them the nutrients phosphorus and nitrogen (Postma, 1982, 1984). In spring and summer,

\section{Wadden Sea}

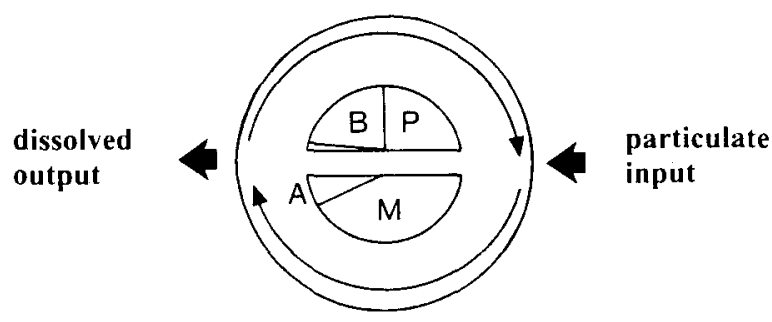

Fig. 4. Metabolism of the Wadden Sea ecosystem. Primary production is primarily accomplished by benthic (B) and pelagic microalgae (P), mineralization by "microorganisms" (M) in a wider sense, and by larger animals $(\mathrm{A})$

end-products of mineralization are taken up by plants within the Wadden Sea. Primary production is accomplished primarily by benthic and pelagic microalgae in about equal proportions (Cadée \& Hegemann, 1977).

In addition to imported seston, this primary production is consumed by microorganisms and the macrobentic fauna, roughly in a 4 to 1 ratio (Kuipers et al., 1981; Wilde \& Beukema, 1984; Witte \& Zijlstra, 1984). About $10 \%$ of the carbon consumed by the macrobenthic fauna is eventually passed on to shrimp, fish and birds in approximately equal proportions. An increased input of organic material during the last decades presumably caused an increase in all major divisions of the carbon cycle (Jonge \& Postma, 1974; Cadée, 1984; Beukema \& Cadée, 1986).

Recently, ecosystem research in the Northern Wadden Sea started with the hypothesis that inputs and outputs were imbalanced (Reise, 1990). Net differences between imports and exports are expected to indicate direction and magnitude of ecosystem change. A major problem is that the quantities transported back and forth with the tides are both large and variable. Consequently, small net differences between inflow and outflow are difficult to measure. Therefore, input-output measurements are performed at four orders of magnitude (Fig. 5).

A bay has been selected where two islands are connected with the mainland by dams along the tidal watersheds, leaving only one way out to the North Sea. Here measurements are undertaken on dissolved substances, particles and organisms in the flood and ebb current. The same is done at a smaller tidal inlet feeding about $1 \%$ of the total area. On a third level, import and export balances are measured at specific habitat structures, 


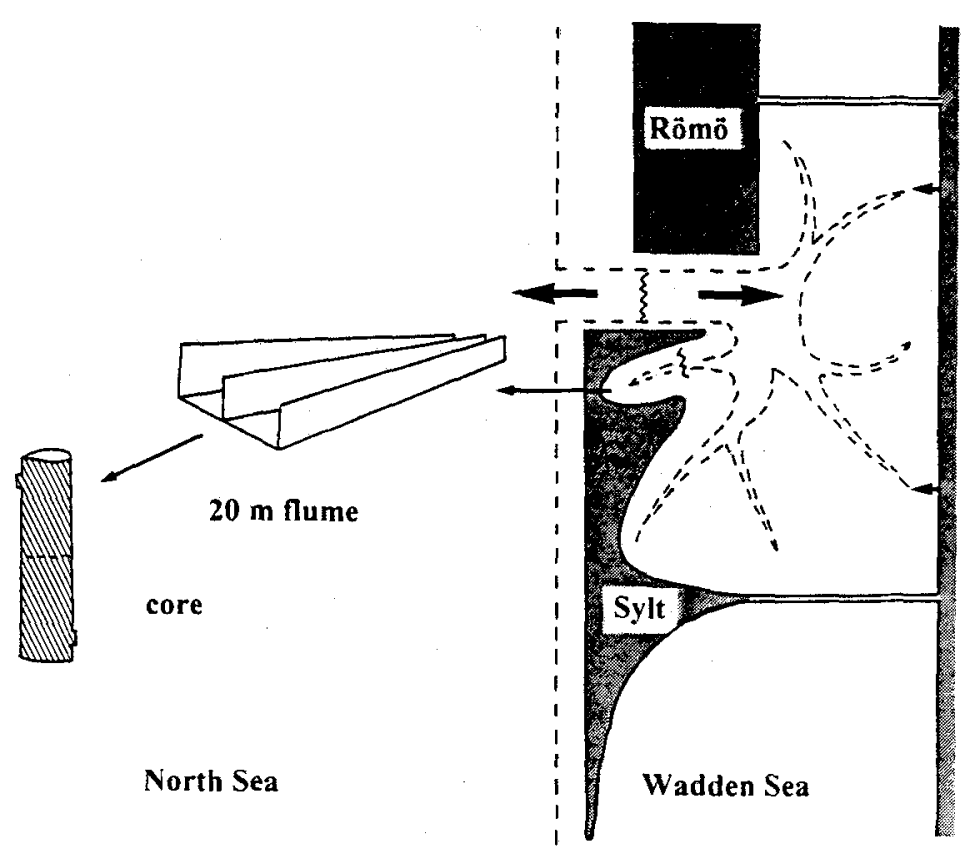

Fig. 5. Exchange processes between the Wadden Sea and the North Sea are measured in the tidal inlet between two islands connected with dams to the mainland, in a tidal channel of a small bay within the area, in the tidal waters of a flume of $20 \mathrm{~m}$ in length set up on specific habitat structures, and in sediment cores or enclosed water parcels

such as mussel beds, by an outdoor flume of $20 \mathrm{~m}$ in length (Asmus et, al., 1990). Samples are taken from the ebb and flood currents passing through this flume. Finally, bacterial processes and gas exchange with the atmosphere are studied in enclosed sediment cores or water parcels.

Another recent endeavour, this one more in the tradition of qualitative ecosystem research, explores the patch dynamics in the intertidal zone of the Wadden Sea. Patches of habitat structure or biotic assemblages are viewed as transient, desynchronized phases of a common, often quasi-cyclical development (Reise, 1991; Fig.6). Patchiness is assumed to slow down an advancing process, and allows for partial independence. The hypothesis is that such mosaic dynamics contribute to homeostatic properties at the landscape level. The idosyncracies of the particular are explored with respect to their effects on the stability and resilience of the whole. Mosaic elements perceived are mussel beds, green algal mats or black spots. The latter are sites where black anoxic sediment approaches the surface from below.

Predictive ecosystem research cannot be content with quantities. The ecological history of the Wadden Sea shows that invading species such as the marsh grass Spartina anglica (Hubbard) or the bivalves Mya arenaria (L.) and Ensis americanus (Binney) significantly change production and biomass. This shows that quantitative ecosystem properties are not independent of the species composition. Qualitative changes are best predicted by research based on experimental manipulations of habitats and speries 


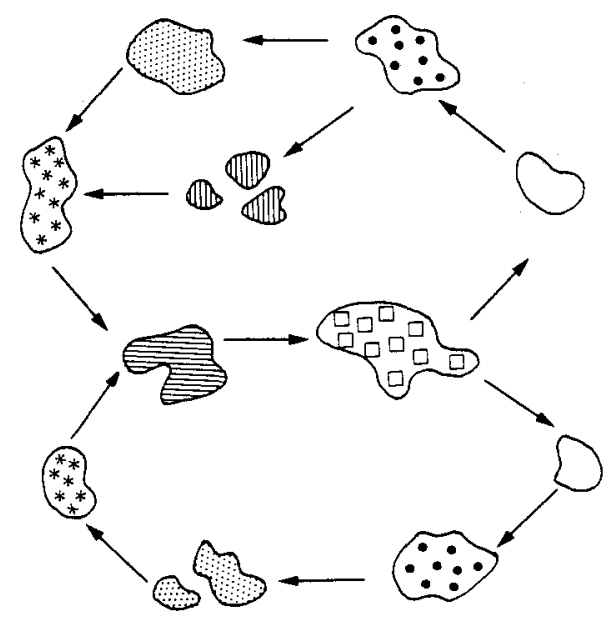

Fig. 6. Mosaic dynamics on tidal flats which may contribute to overall homeostasis by asynchrony, partial independence and singularities

assemblages. The results may then be screened for implications on material flux rates, carbon sources and other quantitative aspects of ecosystem relevance.

\section{CONCLUSIONS}

Ecosystem research provides the most comprehensive knowledge available on specific sections of the biosphere. This knowledge is asked for when familiar features in our environment change, when external processes are expected to alter the boundary conditions for ecosystem functions, or when the ecological implications of optional policies are to be predicted.

Ecological predictions cannot be accurate because of the probabilistic, contingent nature of the ecological processes. However, the reliability that our predictions point in the right direction can be improved by combining different methodologies. (1) Historical ecology: events and developments of the past are used as models for predictions concerning expected situations, which resemble some phases in the past. (2) Quantitative ecosystem research: the sign of imbalances in the import-export relations of the ecotone indicates the rough direction of further ecological developments. (3) Qualitative ecosystem research: field and mesocosm experiments anticipating expected or optional environmental conditions indicate changes in species responses and species composition.

This methodological pluralism of combining historical experience with model calculations based on quantified imbalances in the current processes, and with qualitative insights obtained from anticipatory experiments, afford the best possible robustness for ecological predictions, given the inherent uncertainties.

The historical approach is deficient, because not all conditions relevant for future development were present in the past. For example, although there may be knowledge on several past sequences of global warming similar to the one expected for the next decades, none occurred in conjunction with a nutrient import comparable to present 
conditions. The quantitative approach is deficient because its models incorporate a limited set of compartments, state variables, processes, and units in which the results are expressed. Where the unit is mg carbon, there will be no prediction on species composition. Experiments are deficient, because these are to be conducted on spatial and temporal scales smaller and shorter than those of the system under question, and therefore cannot predict developments which change their course as the dimensions extend. These deficiencies may be partly overcome by a pluralistic approach to predictive ecosystem research concerning the Wadden Sea.

\section{LITERATURE CITED}

Asmus, H., Asmus, R. \& Reise, K., 1990. Exchange processes in an intertidal mussel bed: a Sylt-flume study in the Wadden Sea. - Ber. Biol. Anst. Helgoland 6, 1-79.

Bantelmann, A., 1966. Die Landschaftsentwicklung an der schleswig-holsteinischen Westküste, dargestellt am Beispiel Nordfrieslands. - Küste 14, 5-95.

Beukema, J. J., 1992. Long-term and recent changes in the benthic macrofauna living on tidal flats in the western part of the Wadden Sea. - Publ. Ser. Neth. Inst. Sea Res. 20, 135-141.

Beukema, J. J. \& Cadée, G. C., 1986. Zoobenthos responses to eutrophication of the Dutch Wadden Sea. - Ophelia 26, 55-64.

Bückmann, A., 1934. Über die Jungschollenbevölkerung der deutschen Wattenküste der Nordsee. Ber. dt. wiss. Kommn. Meeresforsch. 7, 205-213.

Cadée, G. C., 1984. Has input of organic matter into the western part of the Dutch Wadden Sea increased during the last decades? - Publ. Ser. Neth. Inst. Sea Res. 10, 71-82.

Cadée, G. C., 1992. Trends in Marsdiep phytoplankton. - Publ. Ser. Neth. Inst. Sea Res. 20, $143-149$.

Cadée, G. C. \& Hegeman, J., 1977. Distribution of primary production of the benthic microflora and accumulation of organic matter on a tidal flat area, Balgzand, Dutch Wadden Sea. - Neth. J. Sea Res. 11, 24-41.

Dahl, F., 1893. Untersuchungen über die Thierwelt der Unterelbe. - Ber. Kommn. wiss. Unters. dt. Meeres 6 (3), 149-185.

Dijkema, K. S., 1987. Changes in salt-marsh areas in the Netherlands Wadden Sea after 1600. In: Vegetation between land and sea. Ed. by A. H. L. Huiskers, C. W. P. M. Blom \& J. Rozema. Junk, Dordrecht, $42-49$.

Dijkema, K. S., van Tienen, G. \& van Beek, J. G., 1989. Habitats of the Netherlands, German and Danish Wadden Sea 1:100,000. Research Institute for Nature Management, Texel, 30 pp.

Frels, G. \& Demuth, A., 1987. Der Jadebusen und seine Watten: Verlandung des Jadebusens oder nur Ausgleich des Meeresspiegelanstiegs? - Küste 45, 117-121.

Garstang, W., 1909. The distribution of the plaice in the North Sea, Skagerak and Kattegat, according to size, age and frequency. - Rapp. P.-v. Réun, Cons. perm. int. Explor. Mer. 11, 65-133.

Grøntved, J., 1962. Preliminary report on the productivity of microbenthos and phytoplankton in the Danish Wadden Sea. - Meddr Danm. Fisk.-og Havunders. 3, 347-378.

Hayes, M. O., 1975. Morphology of sand accumulation in estuaries: an introduction to the symposium. In: Estuarine research. Ed, by L. E. Cronin. Acad. Press, New York, 2, 3-22.

Heydemann, B., 1967. Das Freiland- und Laborexperiment zur Ökologie der Grenze Land - Meer. Verh. dt. zool. Ges. 1967, 256-309.

Heydemann, B., 1979. Responses of animals to spatial and temporal environmental heterogeneity within salt marshes. In: Ecological processes in coastal environments. Ed. by R. L. Jefferies \& A. J. Davy. Blackwell, Oxford, 145-163.

Jonge, V. N. de, Essink, K. \& Bodekke, R, 1993. The Dutch Wadden Sea: a changed ecosystem: Hydrobiologia 265, 45-71.

Jonge, V. N. de \& Postma, H., 1974. Phosphorus in the Dutch Wadden Sea. - Neth. J. Sea Res. 8 , $139-153$.

Kiorbøe, T., Mohlenberg, F. \& Nohr, O., 1981. Effect of suspended bottom material on growth and energetics in Mytilus edulis. - Mar. Biol. 61, 283-288. 
Kuipers, B. R., Wilde, P. A. W. J. de \& Creutzberg, F., 1981. Energy flow in a tidal flat ecosystem. Mar. Ecol. Prog. Ser. 5, 215-221.

Linke, O., 1939. Die Biota des Jadebusenwattes. - Helgoländer wiss. Meeresunters, 1, 201-348.

Michaelis, H., 1987. Bestandsaufnahme des eulitoralen Makrobenthos im Jadebusen in Verbindung mit einer Luftbildanalyse. - Jber. ForschSt. Küste, Norderney 38, 1-97.

Misdorp, R., Steyaert, F., Ronde, J. de \& Hallie, F., 1989. Monitoring the western part of the Dutch Wadden Sea - sea level and morphology. - Helgoländer Meeresunters. 43, 333-345.

Möbius, K., 1877. Die Auster und die Austernwirthschaft. Wiegandt, Hempel \& Parey, Berlin, 126 pp.

Möbius, K., 1893. Über die Tiere der schleswig-holsteinischen Austernbänke, ihre physikalischen und biologischen Lebensverhältnisse. - Jber. preuss. Akad. Wiss. 7, 33-58.

Postma, H. (Ed.), 1983. Hydrography of the Wadden Sea. In: Ecology of the Wadden Sea. Ed. by W. J. Wolff. Balkema, Rotterdam, 1(2), 1-75.

Postma, H., 1984. Introduction to the symposium on organic matter in the Wadden Sea.- Publ. Ser. Neth. Inst. Sea Res. 10, 15-22.

Reise, K., 1980. Hundert Jahre Biozönose. - Naturw. Rdsch., Stuttg. 33, 328-335.

Reise, K., 1985. Tidal flat ecology. Springer, Berlin, $191 \mathrm{pp}$.

Reise, K., 1990. Grundgedanken zur ökologischen Wattforschung. Umweltbundesamt, Berlin, 138-146. (Texte 7/90).

Reise, K., 1990. Karl Möbius: Dredging the first community concept from the bottom of the sea. - Dt. hydrogr. Z. Erg. H. (Reihe B) 22, 149-152.

Reise, K., 1991. Mosaic cycles in the marine benthos. In: The mosaic-cycle concept of ecosystems. Ed. by H. Remmert, Springer, Berlin, 61-82.

Reise, K., Herre, E. \& Sturm, M., 1989. Historical changes in the benthos of the Wadden Sea around the island of Sylt in the North Sea. - Helgoländer Meeresunters. 43, 417-433.

Rosenberg, R., 1985. Eutrophication - the future marine coastal nuisance? - Mar. Pollut. Bull. 16, $227-231$

Smidt, E. L., 1951. Animal production in the Danish Wadden Sea. - Meddr Danm. Fisk.-og Havunders. 11 (6), 1-151.

Streif, H., 1989. Barrier islands, tidal flats, and coastal marshes resulting from a relative rise of sea level in East Frisia on the German North Sea coast. Kluwer, Dordrecht, 213-223.

Thamdrup, H. M., 1935. Beiträge zur Ökologie der Wattenfauna. - Meddr Danm. Fisk.- og Havunders. $10(2), 1-125$.

Vauk, G., Prüter, J. \& Hartwig, E., 1989. Long-term population dynamics of breeding bird species in the German Wadden Sea area. - Helgoländer Meeresunters. 43, 357-365.

Warming, E., 1904. Vadernes, sandenes og marskens naturhistorik. - K. danske Vidensk. Selsk. Skr. $7(2), 1-56$.

Wilde, P. A. W. J. de \& Beukema, J. J., 1984. The role of the zoobenthos in the consumption of organic matter in the Dutch Wadden Sea. - Publ. Ser. Neth. Inst. Sea Res. 10, 145-158.

Witte, J. Y. \& Zijlstra, J. J., 1984. The meiofauna of a tidal flat in the western part of the Wadden Sea and its role in the benthic ecosystem. - Mar. Ecol. Prog. Ser. 14, 129-138.

Wohlenberg, E., 1931. Die Grüne Insel in der Eidermündung. - Arch. dt. Seewarte 50 (2), 1-34.

Wohlenberg, E., 1937. Die Wattenmeer-Lebensgemeinschaften im Königshafen von Sylt. - Helgoländer wiss. Meeresunters. 1, 1-92.

Wohlenberg, E., 1953. Sinkstoff, Sediment und Anwachs am Hindenburgdamm. - Küste 2, 33-93.

Wolff, W. J., 1992a. Ecological developments in the Wadden Sea until 1990. - Publ. Ser. Neth. Inst. Sea Res. 20, 23-32.

Wolff, W. J., 1992b. The end of tradition: 1000 years of embankment and reclamation of wetlands in the Netherlands. - Ambio 21, 287-291.

Wolff, W. J. \& Zijlstra, J. J., 1980. Management of the Wadden Sea. - Helgoländer Meeresunters. 33, $596-613$. 